\title{
Analysis of Market Liberalization and the Groundnut Sector in Senegal
}

\author{
Georges Ndiaye ${ }^{1, *}$, Shaoyong Fang ${ }^{1}$, Beckline Mukete ${ }^{2}$ \\ ${ }^{1}$ School of Economics and Management, Beijing Forestry University, Beijing, China \\ ${ }^{2}$ School of Forestry, Beijing Forestry University, Beijing, China
}

Email address:

georges0144@yahoo.com (G. Ndiaye), seanwork@126.com (S. Fang), munasawa@gmail.com (B. Mukete)

*Corresponding author

To cite this article:

Georges Ndiaye, Shaoyong Fang, Beckline Mukete. Analysis of Market Liberalization and the Groundnut Sector in Senegal. International Journal of Applied Agricultural Sciences. Vol. 4, No. 3, 2018, pp. 43-51. doi: 10.11648/j.ijaas.20180402.13

Received: March 12, 2018; Accepted: April 3, 2018; Published: May 9, 2018

\begin{abstract}
In sub-Saharan Africa, agricultural reforms such as market liberalization and loan schemes greatly affect the agricultural and industrial sectors. The withdrawal of government institutions and adoption of structural adjustment programmes (SAP) have not always been a win-win situation for the different stakeholders of the agricultural sector. This paper assesses the influence of market liberalization on the groundnut sector in Senegal. Using market variables including production, marketing and trade, it analyzes the market performance of groundnuts before and after market liberalization in 2010. The coefficient of variation and the corrected coefficient of variation for producer prices were applied and the results show that the values for both coefficient of variation and corrected coefficient of variation were higher in the pre-liberalization period. There was less volatility after market liberalization and prices were much higher in the post-liberalization period. Market liberalization has generally favoured farmers whereas it has been bad for local processing industries. It is necessary for the government to provide alternative policy interventions to achieve inclusive welfare from market liberalization.
\end{abstract}

Keywords: Market Liberalization, Groundnut Sector, Agriculture, Livelihoods, Senegal

\section{Introduction}

Agriculture plays an important role in the economic growth of many developing countries where it contributes towards food security, job creation, provision of raw material, and trade. For several decades, agricultural policies have formed the frameworks for development policies in many developing countries south of the Sahara $[1,2]$. These policies represent a major tool used by international financial institutions to implement structural adjustment programs (SAP). Agricultural reforms which mainly advocate for market liberalization and withdrawal of government institutions have been the topic of several controversial debates. These debates have resulted from the inconsistency observed in the impacts of SAP and their differential implementation per country $[1,3]$.

Market reform and market liberalization often involve the process of reducing government regulations and restrictions in a market in exchange for greater private sector participation as well as encourage long-term market efficiency and economic development [4-6]. This is because, liberalized markets are free from direct and physical controls imposed by governments. Though a majority of governments adopted these wide market-oriented economic strategies, the degree of market reforms varied significantly among countries and crops. While some countries such as Senegal implemented market liberalization according to SAP, many others reversed the proposed SAP measures [7-8].

Market reform policies aim at boosting a country's economic efficiency while enhancing the productivity of people and physical assets. Meanwhile, in the agricultural sector, market reforms are intended to stimulate a positive supply response by providing farmers with more incentives through higher prices and well-functioning markets. The critical driving force is the increase in producer income, middlemen and the processing industry [4].

In many countries south of the Sahara, these liberalization measures undertaken in the past three decades have been detrimental to the agricultural sector. Additionally, many 
structural and institutional constraints limit agricultural output within these countries $[9,6]$. These constrains include non-price factors, such as the state of infrastructure, availability of marketing services, credit, research and extension services, human capital development, and lack of agricultural reforms. Aside non-price factors, changes in both the physical and environmental dynamics such as rainfall, temperature and soil quality have consequential impacts on agricultural output [9].

In Senegal, agriculture is the mainstay and accounts for over $17 \%$ of the Gross Domestic Product (GDP).

Groundnuts top the chart of major cultivated crops with over $60 \%$ of agricultural GDP, $70 \%$ of agricultural population employment, $35 \%$ of the annual household income, a third of the country's arable land, and $80 \%$ of exports [10-11]. Groundnut is the main export crop in Senegal and from which rural households obtain over $73 \%$ of their annual income [10-12]. According to [13], groundnuts account for over $80 \%$ of farmers' cash income and export earnings. Therefore, groundnut production and marketing play an important role in the national economy and contribute considerably to the subsistence of populations, especially in rural areas. These groundnut products are exported mainly as oil or consumed as grilled or boiled peanuts, or processed into flour, peanut butter, and oil for local consumption $[13,11]$. Groundnut output is first purchased by local milling companies via official marketing channels, which accounts for about $25 \%$ of the national production [14]. Producers are therefore compelled to sell most of their output via unofficial or parallel marketing channels at lower prices.

In Senegal, SAP over the past three decades has been consequential for agricultural output especially in the entire groundnut sector. This liberalization began in the 1980s but not into January 2010 when a further liberalized market allowed groundnut exports. Those involved in the sector were producers, middlemen and millers but after these three decades of lethargy involving direct (via marketing agencies) and indirect (via policies) intervention, the market was liberalized in 2010 [15]. Under this new measure of market liberalization, both foreign and domestic private traders could purchase groundnuts directly from farmers [15-16].

Senegal is the world's leading groundnut oil exporter and where well-functioning and efficient agricultural markets are crucial for the country's economic stability [11]. Also, pricing and marketing policies are among the main factors that affect profitability and competitiveness in the groundnut sector. These policies must be taken into account when discussing the development strategies of groundnuts in Senegal. Therefore, given the place of the groundnut sector in the national economy, it is important to analyze the impact of further liberalizing the market on the welfare of households and the profitability of agribusiness firms.

This paper assesses the socioeconomic impact of market liberalization on the groundnut sector in Senegal. It pays special attention to smallholder farmers in terms of output, income and food security, and on processing industries in terms of processed quantity, exports and profits. From a wider perspective, in order to determine how to mitigate the negative effects of groundnut market liberalization, this paper examines issues related to the approaches and effects of agricultural market reforms in Senegal. Therefore, using data obtained from the Senegalese Institute for Agricultural Research (ISRA) and National Inter-professional Peanut Committee (CNIA), this study aims at understanding the socioeconomic impacts of market liberalization on the groundnut sector in Senegal. This study would contribute to the existing literature on agricultural trade liberalization, particularly its impact on the key players of the agricultural sector.

\section{Materials and Methods}

\subsection{Description of Study Area}

Senegal lies along the coast of northwest Africa with an estimated population of about 15 million inhabitants [17], [18]. It has a tropical climate with a dry season from November to May, and a rainy season from June to October. The dry season is dominated by the hot and dry Harmattan wind around Dakar (the capital city) with average maximum temperatures of $30^{\circ} \mathrm{C}$ and average minimum temperatures of $24.2^{\circ} \mathrm{C}$. Between December and February at the peak of the dry season, maximum temperatures average $25.7^{\circ} \mathrm{C}$ and minimums $18^{\circ} \mathrm{C}$ [11]. Interior temperatures are higher than along the coast. For instance, average daily temperatures in Kaolack and Tambacounda for May are $30^{\circ} \mathrm{C}$ and $32.7^{\circ} \mathrm{C}$ respectively, compared to Dakar's $23.2^{\circ} \mathrm{C}$.

In Tambacounda in the far interior, particularly along the border with Mali where the Sahara desert begins, temperatures can reach as high as $54^{\circ} \mathrm{C}$. Generally speaking, the country is mostly very sunny and dry with average annual rainfall varying between $600 \mathrm{~mm}$ from the north in the Sahel to $1500 \mathrm{~mm}$ in the south along the West African coast. Consequently, the landscape varies considerably, being semidesert in the north, while the south is occupied by the savanna, and with gallery forests along the rivers [11].

Therefore, Senegal's northernmost part has a near hot desert climate, the central part has a hot semi-arid climate and the southernmost part has a tropical wet and dry climate. An estimated $57 \%$ of the population lives in rural areas with agriculture being their major occupation. These rural areas of Senegal, due to over dependence on rain-fed agriculture and low household income face food security issues. These issues are also partly due to the effects of macro-economic shocks such as fiscal adjustments and monetary policy reforms and probably climate variations [11]. Apart from the lack of adequate income sources and resources for better livelihoods, these rural communities also face other challenges such as hunger, malnutrition, and lack of access to basic education, adequate healthcare facilities and involvement in the decision-making process [19]. 


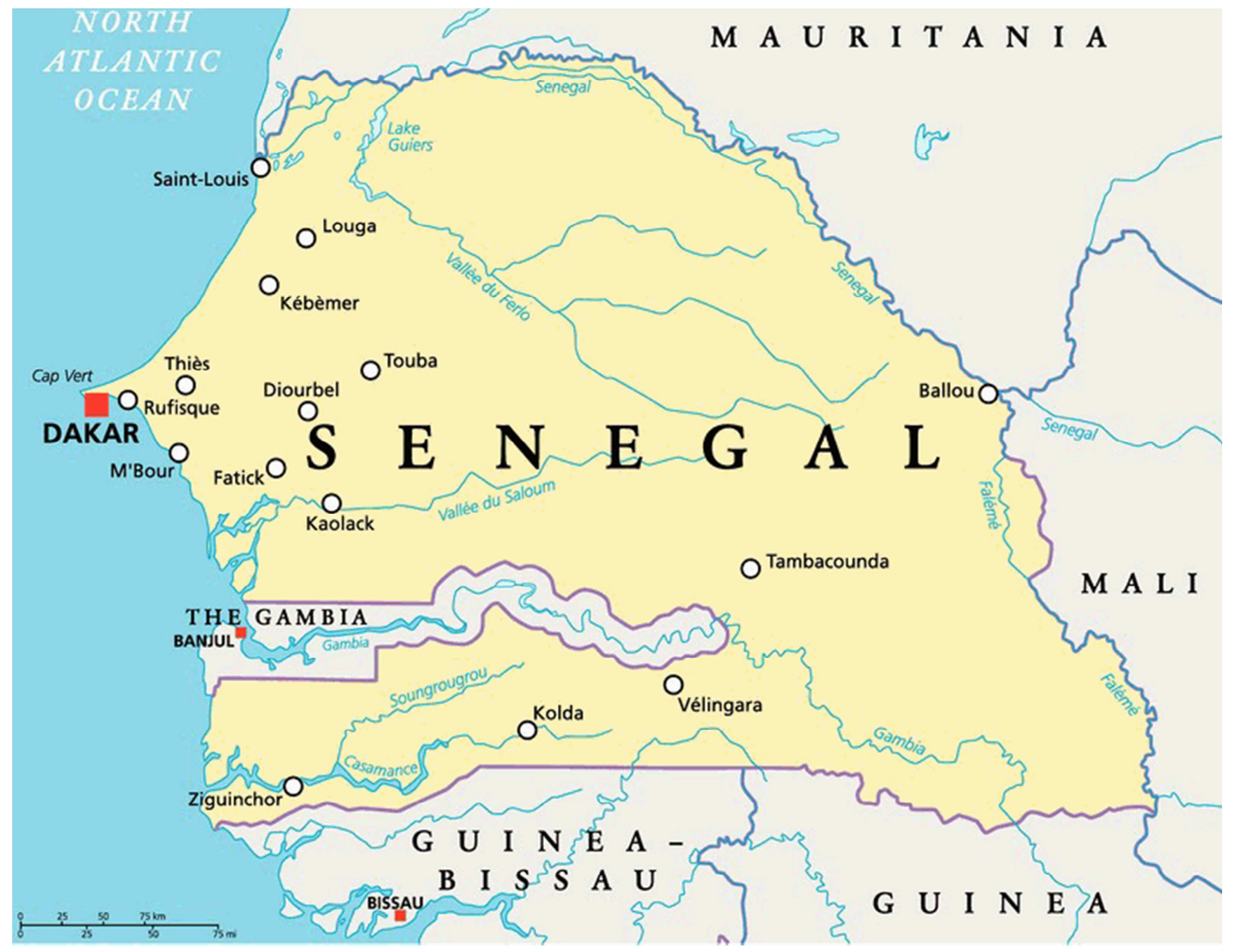

Figure 1. Map of Senegal. Sourced from http://www.yeniasya.com.tr/dunya/senegal-ordusu-gambiya-ya-girdi_421572 11th September, 2017.

\subsection{Data Collection}

To understand the impact of market liberalization on the groundnut sector, data were gathered on factors that could influence annual production (yield). These included seed values; area under cultivation, yield, prices and quantity processed as well as rainfall, temperature, and exports. The data were obtained through interviews using close and openended recall questions, with Senegalese government officials from the Senegalese Institute for Agricultural Research (ISRA) and National Inter-professional Peanut Committee (CNIA), as well as officials from the Food and Agriculture Organization (FAO) and the World Bank (WB) offices in Senegal according to [20].

Data provided by the different sources were obtained between 2000 and 2016 and the ISRA, WB, FAO, and CNIA were selected based on their direct involvement and control of the Senegalese agricultural sector. In instances where potential participants were unable to effectively communicate in French language, the local Wolof language was used to ensure proper understanding. The questionnaires were designed so as to gain an understanding of how market liberation has influenced groundnut production, marketing and trade in Senegal.

\subsection{Data Analysis}

The data were analyzed using Stata 13.0 and Excel 2011. Descriptive statistics were employed for understanding and analyzing the distribution of the data, Coefficient of Variation (CV) and Corrected Coefficient of Variation (CCV) were determined for analyzing the fluctuations of prices and their impact on farmers and processing mills. Meanwhile, Mean analysis to identify the direction of price volatility were also employed while Test of means and equality of variances to determine the statistical significance of results were also carried-out according to [21, 22].

\section{Results}

\subsection{Meteorological Variations}

Figure 2 shows graphical representation of variability in mean annual rainfall in millimeters from 2000 to 2015 for Senegal. There are significant variations in inter-annual rainfall throughout the 15 -year period with consistent drop in 
rainfall peaks from 2000-2002, a rise from 2002-2003 and no particular trends between 2003 and 2015, figure 2.

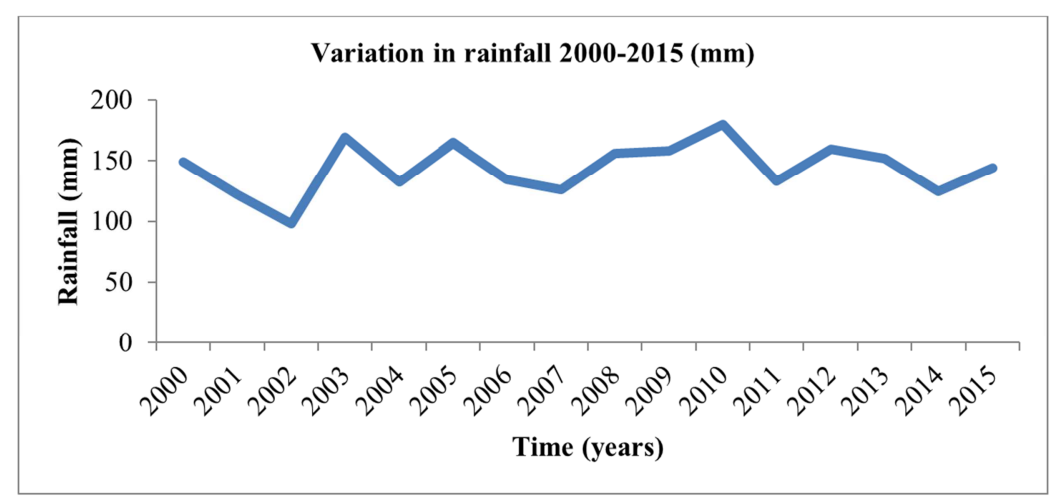

Figure 2. Variation in mean annual rainfall for the period 2000-2015 (mm) in Senegal.

Figure 3 illustrates graphical representation of variability mean annual temperatures $\left({ }^{\circ} \mathrm{C}\right)$ from 2000 to 2015 . Though temperatures have been rising and falling since 2000, it is only in 2015 that a peak is observed between 2012 and 2015 where, 2015 recorded the highest mean annual temperatures of $29.8^{\circ} \mathrm{C}$, figure 3 .

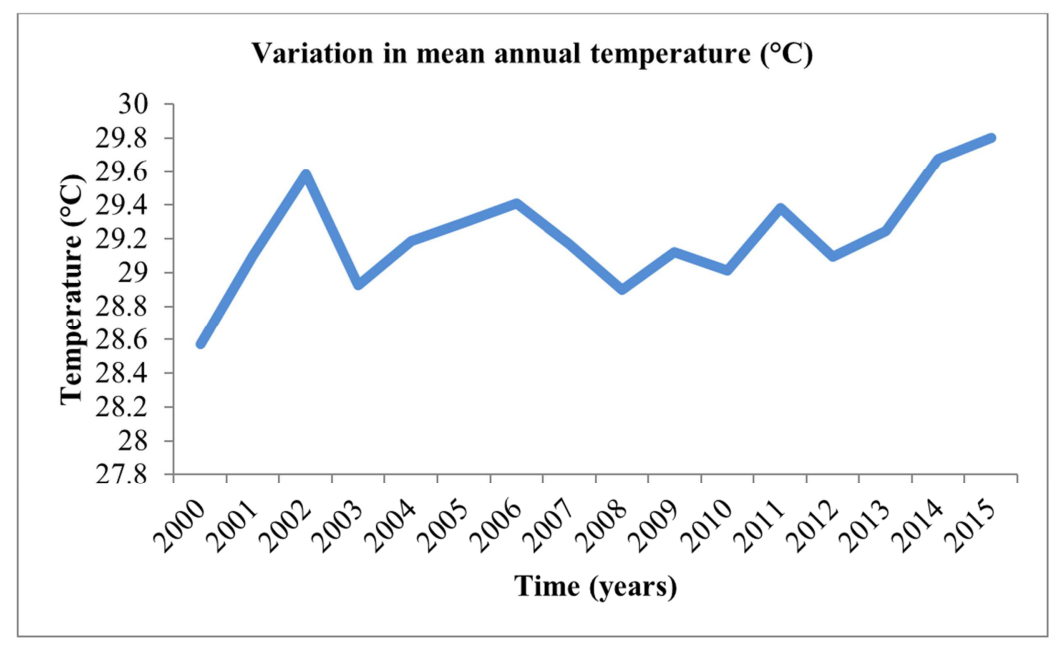

Figure 3. Variation in mean annual temperature for the period $2000-2015\left({ }^{\circ} \mathrm{C}\right)$.

\subsection{Groundnut Production}

Groundnut production in Senegal increased in the postliberalization period (2010-2016) with an annual average production of 843047.9 tons against 645382.5 tons in the preliberalization period (2000-2009). However, there existed some wide fluctuations in both periods, tables 1 and 2 . During the pre-liberalization period, groundnut production was as low as 260723 tons in the marketing year 2002/2003 and as high as 1032651 between 2009 and 2010. During the post-liberalization period, output was as high as 1286855 tons in 2010/2011, which is the year of market liberalization, and as low as 527528 tons in 2011/2012.

Table 1. Groundnut production during the pre-liberalization period 20002009 (tons).

\begin{tabular}{lllll}
\hline & Mean & Std. Dev. & Skewness & Kurtosis \\
\hline Production & 645382.5 & 273271.3 & 0.0924184 & 1.70463 \\
Land & 790705.1 & 180871.9 & 0.0565453 & 1.895432 \\
Yield & 798.3 & 211.5824 & -1.339746 & 3.653656 \\
Rainfall & 141.2453 & 22.45983 & -0.4577956 & 2.284731 \\
Temperature & 29.12646 & 0.2847999 & -0.3433102 & 2.865683 \\
\hline
\end{tabular}

Table 2. Groundnut production during the post-liberalization period 20102016 (tons)

\begin{tabular}{lllll}
\hline & Mean & Std. Dev. & Skewness & Kurtosis \\
\hline Production & 843047.9 & 271869.4 & 0.4960425 & 1.896595 \\
Land & 950174.4 & 182235.3 & 0.2203394 & 1.798738 \\
Yield & 847.9564 & 173.7804 & -0.0464976 & 1.703549 \\
Rainfall & 149.099 & 19.80677 & 0.3681278 & 2.14966 \\
Temperature & 29.36993 & 0.3163169 & 0.2862866 & 1.586645 \\
\hline
\end{tabular}

\subsection{Groundnut Marketing}

The average quantity of groundnuts collected by millers in the post-liberalization period (124825 tons) is about half of what was collected in the pre-liberalization period $(212048$ tons). There was no significant increase in the quantity collected for crushing purposes. For instance, from 1286855 tons produced in 2010/2011, only about 257349 tons were used for crushing, figure 4 . The percentage of output used for processing fell from $55 \%$ in $2000 / 2001$ to an all-time low of $4 \%$ in 2015/2016. The best and worst performances of the groundnut sector in terms of quantity collected by millers 
were respectively before and after market liberalization.

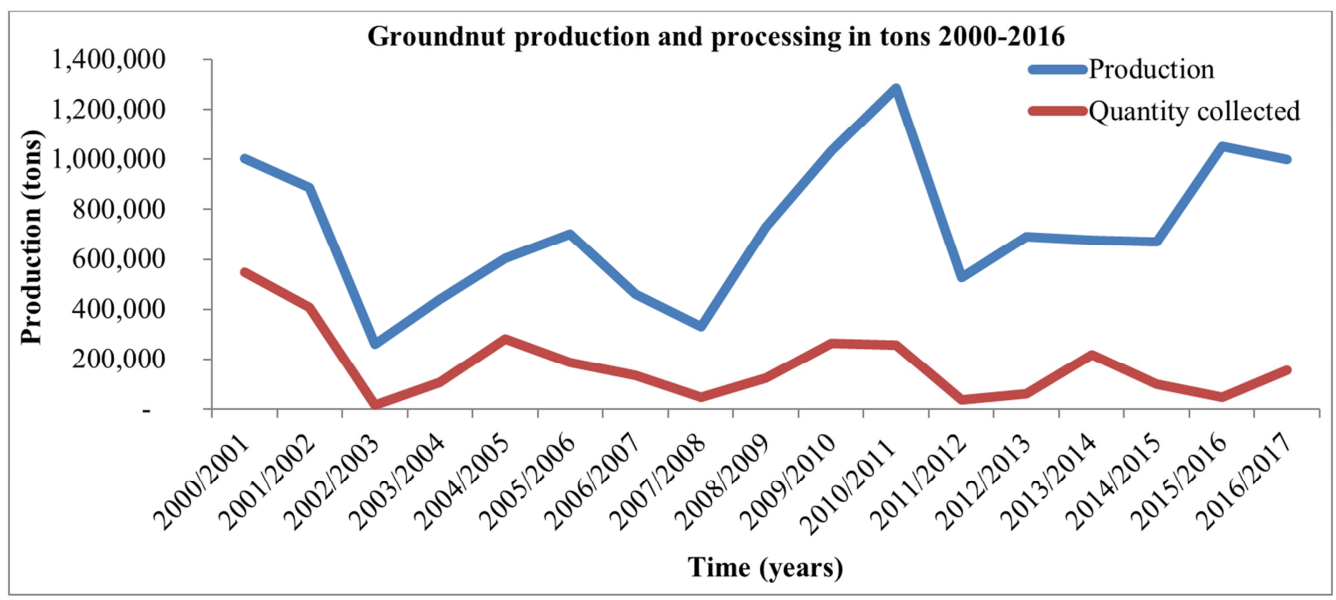

Figure 4. Groundnut production and quantity collected for processing between 2000 and 2016.

\subsection{Groundnut Trade}

The quantity of groundnut oil exported by millers in Senegal decreased over the years from 112876 tons in 2000/2001 to 13008 tons in 2015/2016 or approximately $88 \%$, figure 5. During the 5 years preceding market liberalization, the average groundnut oil export was 41559 tons compared to the 30645 tons of the 5-year post-liberalization period.

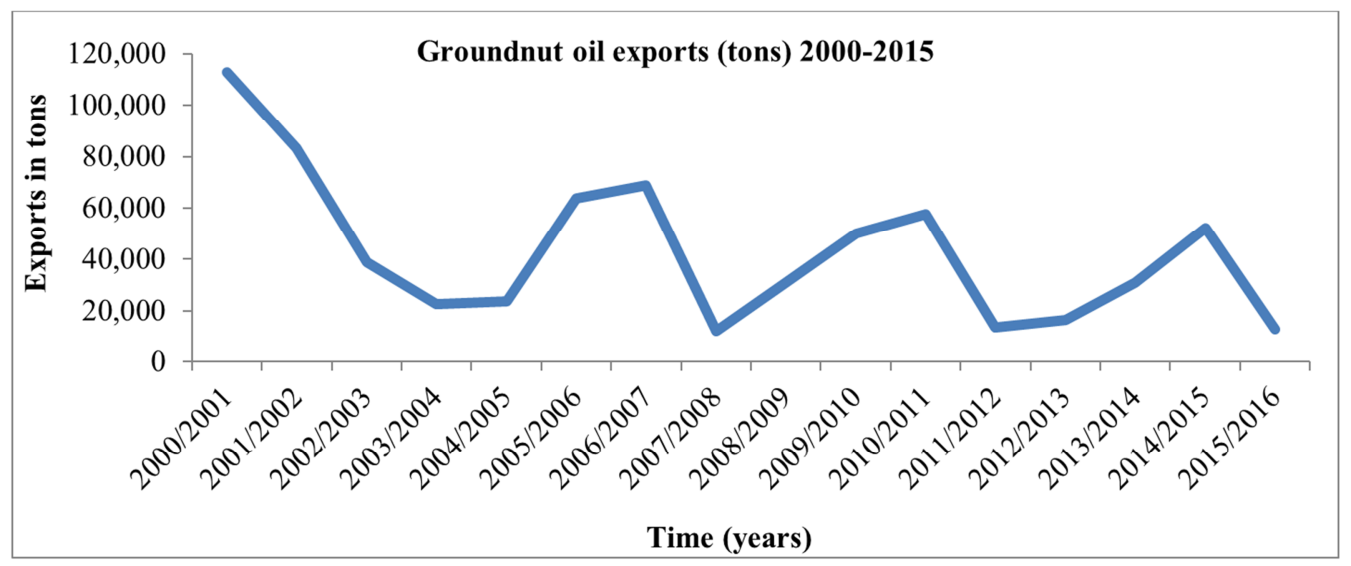

Figure 5. Groundnut oil exports from Senegal for 2000-2015 (tons).

\subsection{Impact of Market Liberalization on Producer Prices}

This section will assess the impact of market liberalization by using the $\mathrm{CV}$ and $\mathrm{CCV}$ to analyze the variations of producer prices in the pre- and post-liberalization periods, and the two-sample t-test to ascertain the significance of observed changes.

\subsubsection{Coefficient of Variation and Corrected Coefficient of Variation of Producer Prices}

Table 3. $C V$ and $C C V$ of the level of official producer prices.

\begin{tabular}{lllll}
\hline \multicolumn{4}{l}{ Pre-liberalization (2000-2009) } & \multicolumn{2}{l}{ Post-liberalization (2010-2016) } \\
\hline CV & CCV & CV & CCV \\
\hline Prices & 10.86 & 5.86 & 8.35 & 2.84 \\
\hline
\end{tabular}

From table 3, it can be seen that producer prices were more volatile during the pre-liberalization period because the $\mathrm{CV}$ is 10.86 , which is greater than that for the post liberalization period of 8.35. The CCV confirms this result because 5.86 is greater than 2.84 .

\subsubsection{Two-Sample t-Test for the Equality of Means}

The Welch-Satterthwaite version of the t-test was used to compare the difference in official producer prices before and after market liberalization. Similarly, the accuracy of the results was tested using the Welch command in Stata 3.0. With $\mathrm{P}<0.05$, the null hypothesis ( $\mathrm{H} 0)$ can be rejected, meaning that the sample means are different. This implies that, prices in the pre- and post-liberalization periods were different. Therefore, the mean difference is negative because post-liberalization prices were subtracted from preliberalization prices. Thus, the mean difference shows groundnut producer prices to be higher after market liberalization, table 4. 
Table 4. Two-sample t test with unequal variances.

\begin{tabular}{llllll}
\hline Group & Observations & Mean & Standard Error & Standard Deviation & 95\% Confidence Interval \\
\hline 0 & 10 & 145.6 & 5.002666 & 15.81982 & 134.2832156 .9168 \\
1 & 7 & 191.4286 & 6.046869 & 15.99851 & 176.6324206 .2247 \\
Combined & 17 & 164.4706 & 6.761764 & 27.87947 & 150.1363178 .8049 \\
Difference & & -45.82857 & 7.848012 & -62.7868 & -28.87034 \\
\hline
\end{tabular}

Diff $=$ mean $(0)$ - mean $(1) ; \mathrm{t}=-5.8395$

Ho: diff $=0$; Satterthwaite's degrees of freedom $=12.9727$

Ha: diff $<0$; Ha: diff! $=0$; Ha: diff $>0$

$\operatorname{Pr}(\mathrm{T}<\mathrm{t})=0.0000 ; \operatorname{Pr}(|\mathrm{T}|>|\mathrm{t}|)=0.0001 ; \operatorname{Pr}(\mathrm{T}>\mathrm{t})=1.0000$

\section{Discussion}

\subsection{Groundnut Production During the pre and Post-Liberalization Periods}

During the post-liberalization period, there was a significant increase in the annual average production than during the pre-liberalization period. This increase might be attributed to other factors of production such as seed quality, market price, increase in fertilizer application and area under cultivation. Despite this variation and increase in production, changing ecological conditions such as rainfall, temperatures, pests and diseases may have affected optimum yield [23], [20]. For instance during the 15 -year period, the area under cultivation increased by over $17 \%$. This increase brought with it an increase in the quantity of seeds planted; hence groundnut yield follows the trend of cultivated area.

\subsection{Meteorological Conditions and Groundnut Production}

The variability in Senegal's ecological zones has an impact on the climate system throughout most of the year. These ecological zones provide for variability in ecological factors including temperature and rainfall variability, soil degradation, pests, and disease. These variations such as decrease in mean monthly rainfall and increase in average monthly temperatures are consequential for crop growth and yield $[24,20]$.

For instance, in Senegal the rainy season is between June and September, typically providing just sufficient water for crops and livestock [25]. Therefore, significant variations usually visualized as a reduction of the areas receiving adequate rainfall for viable agricultural livelihoods, may have retroacted on crop production throughout the 15-year period. This is because, rainfall variability such as duration of the rainy season, number of rainy days and amount of rainfall during each precipitation event, affect crops such as groundnuts, cassava and maize yields [20].

Typically, groundnuts require between $500 \mathrm{~mm}$ and 700 $\mathrm{mm}$ of rain in order to achieve good yields. It is therefore obvious that rainfall variability during the growing season, will greatly affect food crop planting regimes [26, 27, 20]. According to [23, 24], these variations also affect rates of soil erosion and moisture which are prerequisites for staple food crops such as groundnuts, wheat, rice, millet, sorghum, and maize yields. In addition, ground and soil water fluxes are altered as a result of rainfall variability with a consequence for the cropping cycle [28, 29, 23].

Since 2000 , average annual temperatures have increased by almost $0.9^{\circ} \mathrm{C}$ across much of Senegal [30, 11]. Such transitions to warmer climates may limit crop growth and yields as a result of drought effects. As such, regional warming due to very high average air temperatures, often exacerbate the impact of water shortages [31].

\subsection{Market Liberalization and Groundnut Marketing}

Marketing is done through official channels, where minimum prices are set by the CNIA and to local groundnut oil-producing companies. Other farmers sell their produce to licensed exporters and in the informal sector where prices are determined through weekly spot market forces. The market in the informal sector is open all year round and smallholder farmers can sell at higher or lower prices [6]. These buyers include anyone who is willing to buy including small-scale crushing plants and exporters. Therefore, given the importance of groundnut production in Senegal, producer price levels and trends have serious implications for household food security.

Official groundnut producer prices are relatively more stable in the post-liberalization period with relatively higher post-liberalization prices. This price disparity suggests a significant welfare gains for groundnut producers during this period. According to [22], market liberalization can achieve enhanced welfare only by enabling farmers to sell their produce at the highest price in a stable and predictable market. Therefore, by resulting in more stable and relatively higher prices, the liberalization of groundnut market in Senegal is beneficial to farmers. This is because price stability affects the allocation of farmers' limited resources and behaviour. It also increases farmer confidence in the market and food security [32]. By selling at favourable prices, farmers acquire more income while keeping sufficient groundnut stocks for seed and consumption purposes. Moreso, farmers can invest in other inputs for the upcoming growing season while strengthening their purchasing power for other daily foodstuff.

According to [27], since 2012, foreign buyers' especially the Chinese, have been offering smallholder farmers prices up to $30 \%$ higher than the CNIA. This higher demand which overweighs supply has seen a rise in market prices bringing with it an increase in the number of groundnut stocking centers [27, 33, 34]. These new buyers provide producers with more market options for selling their nuts 
and a competitive price advantage. Hence, market liberalization has redistributed revenue transfers in favour of producers. This implies that market reforms have reversed the long-standing discrimination of groundnut farmers [15].

\subsection{Market Liberalization and Groundnut Trade}

The quantity of groundnuts produced during the preliberalization period (2000-2009), was a major force behind groundnut market liberalization in Senegal. In this regard, Decree No. $2010-15$ of $13^{\text {th }}$ January 2010 allowed the exports of all groundnuts except seeds. The decree further paved way for a Memorandum of Understanding (MOU) to be signed between Senegal and China, thus authorizing Chinese traders to purchase groundnuts for export purposes. Groundnut exports from Senegal have preferential access to the Chinese market since no taxes are required which has resulted into large quantities of groundnut exports towards China.

This has made it difficult for local processing mills to acquire raw materials for oil production. Furthermore, it has caused a distortion regarding domestic producer prices, since unprocessed groundnut exports are duty-free, whereas groundnut oil exports are not.

\subsection{Market Liberalization and Groundnut Processing}

Official groundnut producer prices are relatively more stable and higher in the post than in the pre-liberalization period. Therefore, market liberalization has been less beneficial to local groundnut oil-producing industries which use locally produced groundnuts as raw materials. Market liberalization policies have also affected the profitability of processing activities and revenue transfers between production and processing sectors.

In Senegal, market liberalization has increased prices and hence the cost of raw materials for processing industries. Foreign groundnut exporters, purchase large groundnut quantities from smallholder farmers resulting to local price hikes. These price hikes, make it extremely difficult for local millers to satisfy their demand for raw materials. These new dynamics have caused local processing industries to operate at a minimum level due to the shortage of raw materials. For instance, groundnut oilprocessing industries only collected $7.06 \%$ of target groundnut quantity in 2015/2016.

Many groundnut oil-processing industries such as Nouvelle Valorisation d'Arachide du Senegal (NOVASEN) have ceased production and laid-off staff. NOVASEN for instance shutdown in June 2013, because it could only acquire $30 \%$ of the groundnuts it needed to operate at an optimal capacity [35]. Furthermore, market liberalization impacts in Senegal are related to the profitability and competitiveness of groundnut processing activities.

\section{Conclusion}

This study examined the market liberalization in Senegal and how it influences the groundnut sector especially farmers and processing industries. The study also compared the performance of the groundnut sector during the pre and postliberalization periods, in terms of production, marketing, and trade. It showed that market liberalization has various effects on the different players of the groundnut sector. On one hand, the results show that liberalization has been good for farmers on at least three different levels: providing more choice of buyers, delivering prompt cash payments, and providing relatively high producer prices. On the other hand, market liberalization has had devastating consequences for local processing mills: due to the entry of new buyers who make better offers to farmers, local millers are having trouble procuring the groundnut quantities they need to operate at an optimum capacity.

The distributional effects of market liberalization should also be considered, as this will directly distribute revenues into groundnut-producing rural areas. Besides, groundnut exports have a huge impact on the terms of trade in a country like Senegal where imports are much higher than exports.

\section{References}

[1] Oya, C (2006). From state dirigisme to liberalization in Senegal: Four decades of agricultural policy shifts and continuities. The European Journal of Development Research $18(2): 203-234$.

[2] Mukete, B., Sun, Y., Etongo, D., Sajjad, S., Ngoe, M and Tamungang, R (2018a). Cameroon must focus on SDGs in its economic development plans. Environment: Science and Policy for Sustainable Development 60 (2): 25-32.

[3] Mukete, B and Monono, S (2014). Assessing the impact of consumer behaviour on food security in south west Cameroon. Journal of Food Security 2 (3): 87-91.

[4] UN (2006). United Nations Organization. Economic liberalization and poverty reduction Chapter VI: 97-113. http://www.un.org/esa/socdev/rwss/docs/2010/chapter6.pdf. Accessed $25^{\text {th }}$ January 2018.

[5] Kumar, C (2011). A discursive dominance theory of economic reform sustainability: the case of India. India Review10:126184.

[6] Diallo, A., Yin, Z and Mukete, B (2017). Assessing the socioeconomic impacts of the informal sector in Guinea, West Africa. Open Access Library Journal 4: e3290. http://dx.doi.org/10.4236/oalib.1103290.

[7] Jayne, T and Crawford, E (2000). Agricultural input and output market reform: Issues and evidence. Economic policy reforms and agricultural input markets: experiences, lessons, and challenges. Capetown, South Africa: IFDC International Workshop.

[8] Kherallah, M., Delgado, C., Gabre-Madhin, E., Minot, N and Johnson, M (2000). The road half traveled: Agricultural market reform in Sub-Saharan Africa. http://pdf.usaid.gov/pdf_docs/Pnacr621.pdf. Accessed $7^{\text {th }}$ October, 2017. 
[9] Barrett, C and Mutambatsere, E (2005). Agricultural markets in developing countries. In Lawrence E. Blume and Steven N. Durlauf, editors, The New Palgrave Dictionary of Economics, 2nd Edition (London: Palgrave Macmillan). http://dyson.cornell.edu/special_programs/AFSNRM/Parima/ Papers\%20from\%20Cbb2/Papers/CM_agriculturalmarkets.pdf . Accessed 11th September 2017.

[10] Masters, W (2007). Distortions to agricultural incentives in Senegal. Agricultural Distortions Working Paper 41. Washington, D. C.: World Bank.

[11] Ndiaye, G., Fang, S., Mukete, B and Wu, Y. (2016). Potentials of the groundnut sector towards achieving food security in Senegal. Open Access Library Journal, 3:e2991.

[12] Cissé, F., Abdoulaye, D and Cabral, F (2005). Libéralisation de la filière Arachidière et Pauvreté au Sénégal. A paper presented during the 4th PEP Research Network General Meeting June 13-17, 2005, Colombo, Sri Lanka.

[13] Sylla, F (2010). Revitalization of the groundnut sector in West Africa (Gambia, Guinea and Senegal). Global Agricultural Information Network, USDA Foreign Agricultural Service.

[14] Tankari, M (2012). Global price transmission in Senegal's groundnut markets: can smallholders benefit from high international prices? Munich Personal RePEc Archive (MPRA Paper No. 53395).

[15] Badiane, O., Ulimwengu, J and Wouterse, F (2010). Spatial price transmission and market integration in Senegal's groundnut market.

http://ebrary.ifpri.org/cdm/ref/collection/p15738coll2/id/3383. Accessed 30th April 2017.

[16] Cissé, D (2013). Chinese involvement in the Senegalese peanut trade: threat to local markets and processing industries. Centre for Chinese Studies Stellenbosch University. http://www.eldis.org/document/A69697. Accessed 12 ${ }^{\text {th }}$ March 2018.

[17] IFAD (2011)

www.ruralpovertyportal.org/country/statistics/tags/senegal.

[18] ANSD (2016). Agence Nationale de la Statistique et de la Démographie du Senegal. www.ansd.sn.

[19] Sythud, P., Zhang, Y and Mukete, B (2015). Bamboo resources utilization: a potential source of income to support rural livelihoods. Applied Ecology and Environmental Sciences 3: 176-183.

[20] Mukete, B., Sun, Y., Ayonghe, S., Ojong, L., Itoe, C and Tamungang, R (2017a). Adaptation of women to climate variability in the southern slopes of the Rumpi hills of Cameroon. Agriculture, Forestry and Fisheries 5 (6): 272-279.

[21] Huchet-Bourdon, M (2011). Agricultural Commodity Price Volatility: An Overview. OECD Food, Agriculture and Fisheries Papers, No. 52, OECD Publishing, Paris. http://dx.doi.org/10.1787/5kg0t00nrthc-en. Accessed $11^{\text {th }}$ March, 2018.

[22] Chile, L and Talukder, D (2014). The paradox of agricultural trade liberalization in Bangladesh and Tanzania. American Journal of Trade and Policy 1:23-31.
[23] Sonwa, J., Dieye, A., El Mzouri, E et al., (2016). Drivers of climate risk in African agriculture. Climate and Development DOI: 10.1080/17565529.2016.1167659.

[24] Kimengsi, J and Muluh, G (2013). A comparative assessment of the effect of climatic variations on the crops of the Cameroon Development Corporation (CDC): adaptation options. Environment and Natural Resources Research 3 (1):144-156.

[25] USGS (2012). United States Geological Survey. Famine early warning systems network-informing climate change adaptation series. A climate trend analysis of Senegal. https://pubs.usgs.gov/fs/2012/3123/FS12-3123.pdf. Accessed $11^{\text {th }}$ March 2018.

[26] Molua, E and Lambi, C (2007). The economic impact of climate change on agriculture in Cameroon. Policy research working paper 4364. The World Bank Development Research Group. Sustainable Rural and Urban Development Team. http://papers.ssrn.com/sol3/papers.cfm?abstract id=1016260\# PaperDownload. Accessed $11^{\text {th }}$ September, $201 \overline{7}$.

[27] Gro Intelligence - Polishing Peanuts: The Senegalese groundnut story, 20 February 2015. https://grointelligence.com/insights/polishing-peanuts-the-senegalesegroundnut-story?printing=true. Accessed $30^{\text {th }}$ April 2017.

[28] Maddison, D (2006). The perception of and adaptation to climate change in Africa. CEEPA. Discussion Paper No. 10. Centre for environmental economics and policy in Africa. University of Pretoria, Pretoria, South Africa.

[29] Mukete, B., Vermaat, J and Van Straalen, N (2013). Variability in microhabitats prevalence in low lying peat polder ditches of the Netherlands. Applied Ecology and Environmental Research 11 (4): 629-643.

[30] Funk, C., Michaelsen, J. and Marshall, M. (2012) Mapping Recent Decadal Climate Variations in Precipitation and Temperature across Eastern Africa and the Sahel. In: Wardlow, B., Anderson, M. and Verdin, J., Eds., Remote Sensing of Drought-Innovative Monitoring Approaches, Taylor and Francis, London, Chapter 14, 25 p.

[31] Ngoe, M., Jing, Z., Mukete, B., Tabi, G., Kimengsi, J and Aniah, D (2016). Analysis of the technical efficiency of smallholder cocoa farmers in south west Cameroon. American Journal of Rural Development 4 (6): 129-133.

[32] Ngoe, M., Zhou, L., Mukete, B and Bobyeg, P (2018). Cocoa production in Cameroon: a socioeconomic and technical efficiency perspective. International Journal of Agricultural Economics 3 (1): 1-8.

[33] LeQuotidien (2015). Commercialisation de l'arachide Filière: Les Chinois sèment la graine de la mort, $\mathrm{http}: / /$ www.seneweb.com/news/Economie/commercialisationde-1-rsquo-arachide-fi_n_170901.html. Accessed 11th February 2018.

[34] Commodafrica (2016). Les arachides Sénégalaises surfent vers l'Asie. http://www.commodafrica.com/25-01-2016-lesarachides-senegalaises-surfent-vers-lasie. Accessed $10^{\text {th }}$ January 2018.

[35] Jeune Afrique (2013). Sénégal: l'huilier Novasen à l'arrêt, 27 Juin 2013. http://www.jeuneafrique.com/18902/economie/s-ngal-1-huilier-novasen-1-arr-t/. Accessed 4th May, 2018. 